Short Communication

\title{
Determination of water-soluble and total extractable polyphenolics in biomass, necromass and decomposing plant material using near-infrared reflectance spectroscopy (NIRS)
}

\author{
Marie-Madeleine Coûteaux ${ }^{\mathrm{a}, *}$, Lina Sarmiento ${ }^{\mathrm{b}}$, Dominique Hervéc ${ }^{\mathrm{c}}$, Dimas Acevedo ${ }^{\mathrm{b}}$ \\ ${ }^{a}$ Centre National de la Recherche Scientifique, Centre d'Ecologie Fonctionnelle et Evolutive, 1919 Route de Mende, F-34293 Montpellier Cedex 5, France \\ ${ }^{\mathrm{b}}$ Instituto de Ciencias Ambientales y Ecológicas, Facultad de Ciencias, Universidad de los Andes, Mérida 5101, Venezuela \\ 'Institut de Recherche pour le Développement, IRD, LER, BP 64501, F34394 Montpellier Cedex 5, France
}

Received 22 July 2003; accepted 23 August 2004

\begin{abstract}
Near infrared reflectance spectroscopy (NIRS) was used to predict the water-soluble and total extractable polyphenolics of plant material. Different life forms (forbs, grasses, shrubs, giant rosettes), organs (leaves, stems, roots) and decomposition stages (biomass, necromass and decomposing plant material) were studied. Prediction was good, with a $\mathrm{R}^{2}$ in validation ranging from 0.91 to 0.93 and in prediction from 0.88 to 0.94 . Various standard error ratios were used to assess the quality of the models, which are generally very good, being the model for predicting the water-soluble polyphenolics in the decomposing plant material the slightly less good. Because it is a cheap and rapid method, it would allow to perform a large screening for studies concerning (i) polyphenolics control on decomposition process and (ii) phenolics implication in herbivory.
\end{abstract}

(C) 2004 Elsevier Ltd. All rights reserved.

Keywords: Near infrared reflectance spectroscopy; Polyplenols; Plant material quality; Decomposition

Near infrared reflectance spectroscopy (NIRS) is a rapid, cheap and non-destructive technique offering the potential for accurate and repeatable measurements of chemical constituents in organic materials (Norris et al., 1976; Williams, 1975). In litter decomposition studies, it has been used to determine neutral and acid detergent fibres (NDF and ADF) and acid detergent lignin (ADL) as extracted by the van Soest technique (Van Soest and Robertson, 1985; Joffre et al., 1992; Coûteaux et al., 1998; Mc Tiernan, 1998 unpublished PhD; Kurz-Besson, 2000 unpublished $\mathrm{PhD}$; McTiernan et al., 2003); mass loss (Gillon et al., 1993; Kurz-Besson, 2000 unpublished PhD) or decomposability (Gillon et al., 1999). NIRS calibration of phenolic substances was carried out in some food materials, such as tea leaves (Schulz et al., 1999), or some forage species (Windham et al., 1988).

\footnotetext{
* Corresponding author. Tel.: +33467 6132 82; fax: +33467412138.

E-mail address: marie-madeleine.couteaux@cefe.cnrs.fr (M.-M. Coûteaux).
}

The NIRS determination is based in the use of regression models between the spectral information of a set of samples and their reference values. In this paper, we attempt to fit regression models to total and water-soluble extractable polyphenol content (TEP and WEP) of undecomposed (biomass and necromass) and decomposing plant material. These models would be an easy tool for rapid determination of phenolic compound content in plant material. These compounds are known to be a defence strategy of plants against herbivory (Hanley and Lamont, 2002; Kouki and Manetas, 2002) and a factor controlling plant residue decomposition rate (Northup et al., 1998; Loranger et al., 2002).

The plant material came from two studies: (i) a decomposition experiment where litter bags of 14 species were incubated for 1-2 years in two sites located in the high altitude Andes (Patacamaya in Bolivia at $3800 \mathrm{~m}$ asl and Gavidia in Venezuela at $3400 \mathrm{~m}$ asl) providing more than 3700 samples in different stages of decomposition (DECO set), and (ii) a production study at Gavidia providing 430 samples from 24 additional species (PROD set) (Table 1). Different life forms 
Table 1

Number of samples of the different kinds of plant material used for the conventional polyphenolics analyses

\begin{tabular}{|c|c|c|c|c|c|c|c|c|c|}
\hline \multirow[t]{2}{*}{ Species } & \multirow[t]{2}{*}{ Family } & \multirow[t]{2}{*}{ Site } & \multicolumn{4}{|c|}{ Undecomposed } & \multicolumn{3}{|c|}{ Decomposing } \\
\hline & & & Biomass & $\begin{array}{l}\text { Necro- } \\
\text { mass }\end{array}$ & Litter & Roots & Leaves & Stems & Roots \\
\hline \multicolumn{10}{|l|}{ DECO study } \\
\hline Bitter potatoes & Solanaceae & Patacamaya & & 2 & & & 3 & 2 & \\
\hline Sweet potatoes & Solanaceae & Patacamaya & & 1 & & & 3 & 1 & \\
\hline Sheep dung & & Patacamaya & & 1 & & & 7 & & \\
\hline Aristida asplundii & Poaceae & Patacamaya & & & & 1 & 2 & & \\
\hline Bouteloua simplex & Poaceae & Patacamaya & & 1 & & & 2 & & \\
\hline Erodium cicutarium & Geraniaceae & Patacamaya & & & & & 4 & & \\
\hline Festuca orthophylla & Poaceae & Patacamaya & & & & 1 & 1 & & \\
\hline Oxalis bisfracta & Oxalidaceae & Patacamaya & & & & 1 & & & \\
\hline Baccharis incarum & Asteraceae & Patacamaya & & & & 1 & 1 & 3 & 1 \\
\hline Parastrephia lepidophylla & Asteraceae & Patacamaya & & 1 & & & & 3 & \\
\hline Stipa ichu & Poaceae & Patacamaya & & & & & 2 & & 1 \\
\hline Triticum aestivum & Poaceae & Patacamaya & & & & & 6 & & \\
\hline \multicolumn{10}{|l|}{ DECO and PROD studies } \\
\hline Acaena elongata & Rosaceae & Gavidia & 3 & & 1 & 2 & 2 & & 2 \\
\hline Baccharis prunifolia & Asteraceae & Gavidia & 2 & 1 & 1 & 1 & 2 & & 3 \\
\hline Espeletia schultzii & Asteraceae & Gavidia & 2 & & 1 & 1 & 3 & & 2 \\
\hline Hypericum laricifolium & Guttiferae & Gavidia & 4 & 1 & & 2 & 4 & & 1 \\
\hline Lupinus meridianus & Fabaceae & Gavidia & 2 & & 1 & & 2 & 2 & 3 \\
\hline Mixed roots & several & Gavidia & & & & & & & 1 \\
\hline Solanum tuberosum & Solanaceae & Gavidia & & & & 1 & 3 & 2 & 1 \\
\hline Rumex acetosella & Polygonaceae & Gavidia & 4 & & 5 & & 2 & & 2 \\
\hline Vulpia myurus & Poaceae & Gavidia & 1 & & & & 2 & & \\
\hline \multicolumn{10}{|l|}{ PROD study } \\
\hline Agrostis jahnii & Poaceae & Gavidia & 3 & & 1 & & & & \\
\hline Agrostis trichodes & Poaceae & Gavidia & 2 & & 1 & & & & \\
\hline Arenaria venezuelana & $\begin{array}{l}\text { Caryophylla- } \\
\text { ceae }\end{array}$ & Gavidia & 3 & & 1 & & & & \\
\hline Baccharis tricuneata & Asteraceae & Gavidia & 1 & & 1 & & & & \\
\hline Bidens triplenervia & Asteraceae & Gavidia & 3 & & 1 & & & & \\
\hline Bromus carinatus & Poaceae & Gavidia & 3 & 1 & 3 & & & & \\
\hline Calamagrostis pittieri & Poaceae & Gavidia & 1 & & & & & & \\
\hline Cerastium racemosum & $\begin{array}{l}\text { Caryophylla- } \\
\text { ceae }\end{array}$ & Gavidia & 1 & & 1 & & & & \\
\hline Erodium cicutarium & Geraniaceae & Gavidia & & 1 & & & & & \\
\hline Gamochaeta americana & Asteraceae & Gavidia & & & 3 & & & & \\
\hline Geranium chamaense & Geraniaceae & Gavidia & & & 1 & & & & \\
\hline Geranium multiceps & Geraniaceae & Gavidia & 1 & & 1 & & & & \\
\hline Gnaphalium meridanum & Asteraceae & Gavidia & 1 & & & & & & \\
\hline Lachemilla moritziana & Rosaceae & Gavidia & 1 & 1 & 2 & & & & \\
\hline Myrica pubescens & Myricaceae & Gavidia & 3 & & 1 & & & & \\
\hline Noticastrum marginatus & Asteraceae & Gavidia & 1 & & 1 & & & & \\
\hline Oenothera epilobifolia & Onagraceae & Gavidia & 1 & & & & & & \\
\hline Orthosanthus chimboracensis & Iridaceae & Gavidia & 2 & 1 & & & & & \\
\hline Penisetum clandestinum & Poaceae & Gavidia & 2 & & & & & & \\
\hline Sisyrinchium tinctorum & Iridaceae & Gavidia & 3 & 1 & 2 & & & & \\
\hline Stevia elatior & Asteraceae & Gavidia & 1 & & 1 & & & & \\
\hline Trisetum irazuense & Poaceae & Gavidia & 2 & 2 & & & & & \\
\hline Root biomass + necromass & several & Gavidia & 4 & & & & & & \\
\hline Root biomass & several & Gavidia & 3 & & & & & & \\
\hline
\end{tabular}

(forbs, grasses, shrubs and giant rosettes) and organs (leaves, stems and roots) were studied, and comparisons were done between biomass, necromass and litter.

The samples were ground $(1 \mathrm{~mm})$ using a centrifugal mill (Cyclotec, Perstorp Analytical) and then packed into sample cells with a quartz (minimal reflectance) window. Infrared analysis was carried out using a NIR spectrophotometer
(NIRSystems 6500, Perstorp Analytical) (Coûteaux et al., 1998; McTiernan et al., 1998; Kurz Besson 2000 unpublished $\mathrm{PhD}$, McTiernan et al., 2003), which covers a spectral range of 400-2500 nm (i.e. visible and near infrared). Data were collected at $2 \mathrm{~nm}$ intervals giving a spectrum with 1050 data points. The sample cell was rotated during scanning and the energy reflected back from the sample was measured and 
Table 2

Range of variation of water-soluble (WEP) and total extractable (TEP) polyphenols content $\left(\mathrm{g} \mathrm{kg}^{-1} \mathrm{DW}\right)$ of the reference values

\begin{tabular}{|c|c|c|c|c|c|c|}
\hline & $n$ & Mean & Median & Minimum & Maximum & $\mathrm{SD}$ \\
\hline \multicolumn{7}{|l|}{ Decomposing plant material } \\
\hline WEP & 96 & 8.6 & 3.17 & 0.24 & 95.15 & 16.28 \\
\hline TEP & 96 & 22.04 & 10.45 & 0.7 & 157.83 & 29.36 \\
\hline \multicolumn{7}{|c|}{ Undecomposed plant material } \\
\hline WEP & 101 & 36.85 & 16.29 & 2.09 & 233.28 & 51.91 \\
\hline TEP & 101 & 64.56 & 32.43 & 5.97 & 321.17 & 72.16 \\
\hline
\end{tabular}

recorded. Each spectrum comprised 64 averaged scans of the rotating sample. Reflectance was converted to absorbance $(A)$ values via the following equation:

$A=\log (1 / R)$

where $R$ is the ratio of the reflectance of the sample to a reference standard.

More than 4000 spectra were collected. Data analyses were performed using WinISI II-version 1.02a software (Foss NIRSystems/Tecator, Infrasoft International, LLC). A sub-set of 96 samples was selected from the DECO set by elimination of samples with close spectra using a principal component analysis (PCA) performed on the global spectral information (DECO selection) after checking on their normal distribution. On this selected set, conventional analyses were performed in order to build up calibration models. Then the spectra of the PROD set were compared to the average spectrum of the DECO selection, using the Mahalanobis distance $H$ (Mahalanobis, 1936) in order to test if the calibration models based on the DECO selection may be used to predict their chemical composition. For 140 spectra of the PROD set, the $H$ value was higher than 3, which is the threshold used for eliminating outliers, indicating that the regression model for the DECO set was not appropriate for the PROD set. Therefore, calibration models for the PROD set were built up on a selection of 101 samples (PROD selection) on which conventional analyses were performed.

Conventional analyses were performed according to the TSBF method (Anderson and Ingram, 1993): watersoluble compounds (WEP) were extracted by mixing $1 \mathrm{~g}$ of plant material with $60 \mathrm{ml}$ of cold water during $2 \mathrm{~h}$ and centrifuged for $8 \mathrm{~min}$ at $1500 \mathrm{~g}$; methanol-soluble compounds (TEP) were extracted by heating the residue of water extraction at $80^{\circ} \mathrm{C}$ in $50 \mathrm{ml}$ of $50 \%(\mathrm{v} / \mathrm{v})$ methanol in water for one hour and centrifuged for $8 \mathrm{~min}$ at $1500 \mathrm{~g}$. The phenolic compounds were determined with a colorimeter (DR/890- HACH company, Colorado, USA) in both supernatants with the $\mathrm{HACH}^{\mathrm{TM}}$ method no 8193 (Anonymous, 1999) using Tanniver ${ }^{\circledR} 3$ TanninLignin reagent as tyrosine reagent according to the Folin Ciocalteu principle which takes into account all hydroxyl aromatic compounds (Chapuis-Lardy et al., 2002). Phenolics were expressed as tannic acid equivalent. In an evaluation of the methods for measuring phenolics,
$\mathrm{Yu}$ and Dahlgren (2000) suggested that the Folin Ciocalteu method provides a rapid test for the characterization of extractable phenolics which may have a great physiological and/or ecological significance.

The ranges of variation of the reference values are given in Table 2. The mean values of the DECO selection were lower than those of the PROD selection probably due to the leaching of the polyphenolics during the decomposition process or the decrease of extractability (Maie et al., 2003). The medians were lower than the means because of the low number of samples with high concentrations. In the DECO selection, the samples with a high concentration were generally the initial material (senescent material) and in the PROD selection generally the green leaves. In both sub-sets the range of variation was large.

The calibration models were built up on both DECO and PROD selections using least square mean multiple regressions between the measured concentrations and the wavelengths of the spectra (256 variables). The characteristics of the calibration equations are given in Table 3.

Cross validation was used to determine the optimal number of terms for the calibration. The calibration set was arbitrarily divided into four groups. Three groups were selected for developing the model and the fourth for prediction. This validation procedure was performed four times, to use all samples for both model development and prediction. The residuals of the four predictions were pooled to provide a standard error of cross validation (SECV). All the samples were used to calculate the final model and the residuals give the standard error of calibration (SEC).

Different criteria are generally used to assess the quality of the models. The coefficient of determination $\mathrm{R}^{2}$, the most commonly used, should be higher than 0.8 for quantitative predictions. For excellent models, the SEC-to-SD ratio should be $\leq 0.2$, where SD is the standard deviation of the reference values. If $0.2<$ SEC-to-SD ratio $\leq 0.5$, quantitative predictions is possible (Coûteaux et al., 2003). The SDto-SECV ratio should be $\geq 2$ (Chang et al., 2001; Chang and Laird, 2002), SEP-to-SEC $\leq 1.2$ and the SD-to-SEP ratio should be $\geq 2.5$ (Mathison et al., 1999). In this study the $\mathrm{R}^{2}$ value ranged from 0.90 to 0.93 , the SEC-to-SD ratio from 0.27 to 0.32 , SD-to-SECV ratio from 1.3 to 2.2 , the SEP-toSEC ratio from 0.97 to 1.25 and the SD-to-SEP from 2.69 to 
Table 3

NIRS calibration and validation statistics

\begin{tabular}{|c|c|c|c|c|c|c|c|c|c|c|c|c|c|c|c|c|}
\hline \multirow{2}{*}{$\begin{array}{l}\text { Para- } \\
\text { meters }\end{array}$} & \multicolumn{8}{|c|}{ Calibration } & \multicolumn{4}{|c|}{ Validation } & \multicolumn{4}{|c|}{ Quality parameters } \\
\hline & $N$ & $\begin{array}{l}\text { Term } \\
\text { num- } \\
\text { bers }\end{array}$ & $\begin{array}{l}\mathrm{X} \text {-out- } \\
\text { liers }\end{array}$ & $\begin{array}{l}\text { Math } \\
\text { treat- } \\
\text { ment }\end{array}$ & $\begin{array}{l}\mathrm{SEC}^{\mathrm{a}} \\
\left(\mathrm{g} \mathrm{kg}^{-1}\right. \\
\mathrm{DW})\end{array}$ & $\mathrm{SD}^{\mathrm{a}}$ & SECV & $\mathrm{R}^{2}$ & $n$ & $\begin{array}{l}\mathrm{X} \text {-out- } \\
\text { liers }\end{array}$ & $\begin{array}{l}\mathrm{SEP}^{\mathrm{a}} \\
\left(\mathrm{g} \mathrm{kg}^{-1}\right. \\
\mathrm{DW})\end{array}$ & $\mathrm{R}^{2}$ & $\begin{array}{l}\mathrm{SEC} / \\
\mathrm{SD}\end{array}$ & $\begin{array}{l}\text { SD/ } \\
\text { SECV }\end{array}$ & $\begin{array}{l}\mathrm{SD} / \\
\mathrm{SEP}\end{array}$ & $\begin{array}{l}\text { SEP/ } \\
\text { SEC }\end{array}$ \\
\hline \multicolumn{17}{|c|}{ Decomposing plant material } \\
\hline $\mathrm{WEP}^{\mathrm{a}}$ & 84 & 8 & 9 & $2,4,4$ & 1.92 & 6.427 & 5.06 & 0.911 & 90 & 6 & 2.39 & 0.919 & 0.30 & 1.3 & 2.69 & 1.25 \\
\hline $\mathrm{TEP}^{\mathrm{a}}$ & 86 & 8 & 7 & $2,8,4$ & 6.10 & 20.24 & 10.28 & 0.910 & 90 & 6 & 7.11 & 0.887 & 0.30 & 2.0 & 2.85 & 1.17 \\
\hline \multicolumn{17}{|c|}{ Undecomposed plant material } \\
\hline $\mathrm{WEP}^{\mathrm{a}}$ & 94 & 8 & 7 & $2,6,4$ & 11.39 & 42.58 & 18.98 & 0.928 & 95 & 6 & 11.1 & 0.938 & 0.27 & 2.2 & 3.85 & 0.97 \\
\hline $\mathrm{TEP}^{\mathrm{a}}$ & 94 & 6 & 7 & $2,4,4$ & 20.13 & 63.53 & 28.87 & 0.900 & 95 & 6 & 22.0 & 0.883 & 0.32 & 2.2 & 2.89 & 1.09 \\
\hline
\end{tabular}

a Abbreviations are explained in the text

3.85. The best models were obtained for WEP and TEP using the PROD selection and TEP with the DECO selection. The model for WEP using the DECO selection was less good with nevertheless an $\mathrm{R}^{2}$ of 0.91 that allows a rough quantitative evaluation.

Fig. 1 shows the predicted values plotted against the measured values for WEP and TEP concentrations of the DECO and the PROD selections. The $\mathrm{R}^{2}$ of the linear

\section{WEP $\left(\mathrm{mg} \mathrm{g}^{-1}\right)$}
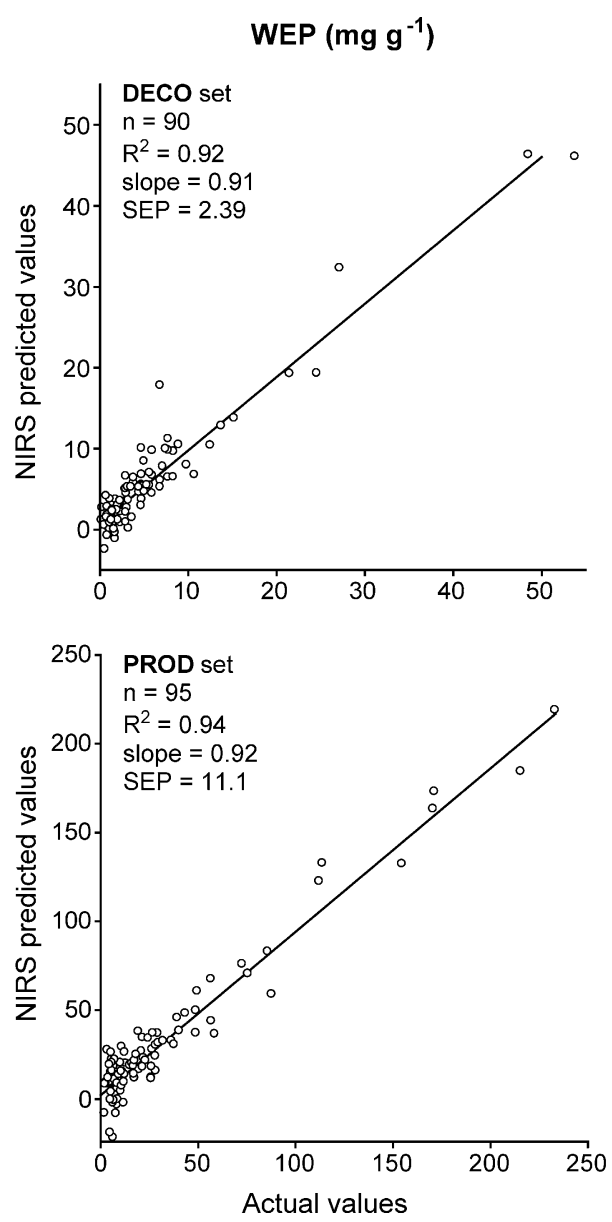

regression ranged from 0.88 to 0.94 , the slope from 0.86 to 0.92 , which confirm the good quality of the models.

It can be concluded that NIRS can accurately determine the content of water-soluble and total extractable polyphenolics for a large range of concentrations and kinds of plant materials. Because it is a cheap, rapid and nondestructive method, it would allow performing a large screening for studies concerning (i) polyphenolic control on
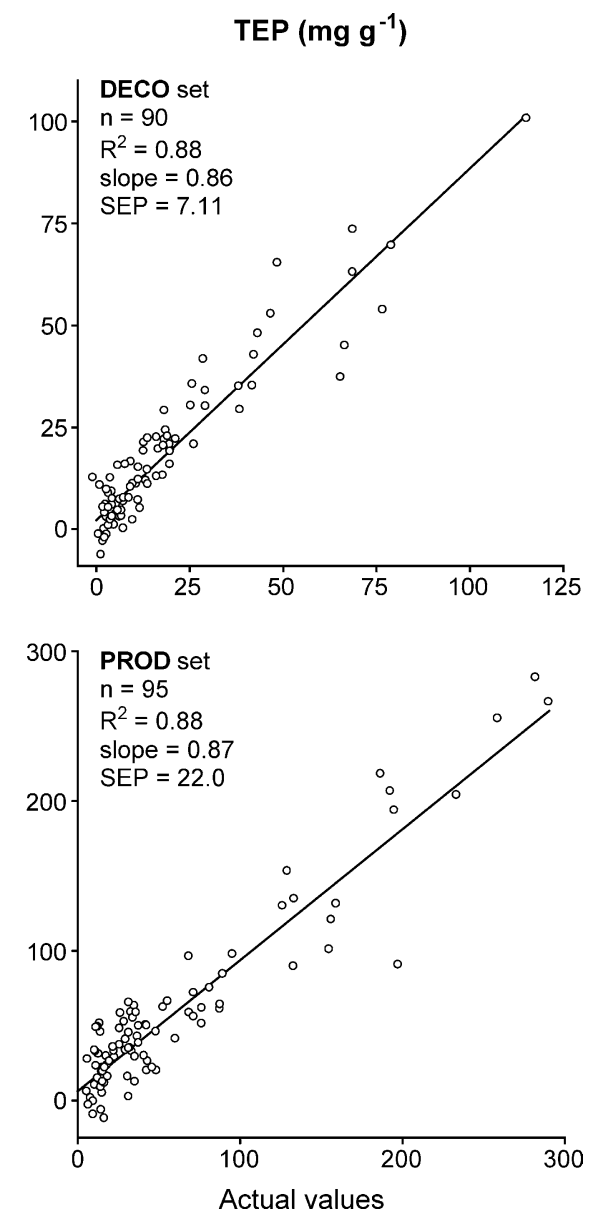

Fig. 1. Relationship between NIRS-predicted and measured water-soluble extractable polyphenolics (WEP) and total extractable polyphenolics (TEP) concentration in the DECO and the PROD selected samples. 
decomposition process and (ii) polyphenolic implication in herbivory and adaptive mechanisms of plants.

\section{References}

Anderson, J.M., Ingram, J.S.I., 1993. Tropical soil biology and fertility, A Handbook of Methods. C.A.B. International. $221 \mathrm{pp}$.

Anonymous, 1999. HACH Colorimetre DR/890 Méthodes d'analyses HACH CompanyLoveland, Colorado, USA. 398-399 pp.

Chang, C.W., Laird, D.A., 2002. Near-infrared reflectance spectroscopic analysis of soil C and N. Soil Science 167, 110-116.

Chang, C.W., Laird, D.A., Mausbach, M.J., Hurburgh, C.R., 2001. Nearinfrared reflectance spectroscopy-principal components regression analyses of soil properties. Soil Science Society of America Journal $65,480-490$.

Chapuis Lardy, L., Contour Ansel, D., Bernhard-Reversat, F., 2002. Highperformance liquid chromatography of water-soluble phenolics in leaf litter of three Eucalyptus hybrids (Congo). Plant Science 163, 217-222.

Coûteaux, M.M., McTiernan, K.B., Berg, B., Szuberla, D., Dardenne, P., Bottner, P., 1998. Chemical composition and carbon mineralisation potential of Scots pine needles at different stages of decomposition. Soil Biology and Biochemistry 30, 583-595.

Coûteaux, M.M., Rovira, P., Berg, B., 2003. Near infrared reflectance spectroscopy for determination of organic matter fractions including microbial biomass in coniferous forest soils. Soil Biology and Biochemistry 35, 1587-1600.

Gillon, D., Joffre, R., Dardenne, P., 1993. Predicting the stage of decay of decomposing leaves by near-infrared spectroscopy. Canadian Journal of Forest Research 23, 2552-2559.

Gillon, D., Joffre, R., Ibrahima, A., 1999. Can litter decomposability be predicted by near infrared reflectance spectroscopy? Ecology 80, $175-186$.

Hanley, M.E., Lamont, B.B., 2002. Relationships between physical and chemical attributes of congeneric seedlings: how important is seedling defence? Functional Ecology 16, 216-222.

Joffre, R., Gillon, D., Dardenne, P., Agneessens, R., Biston, R., 1992. The use of near-infrared reflectance spectroscopy in litter decomposition studies. Annales des Sciences Forestières 49, 481-488.

Kouki, M., Manetas, Y., 2002. Toughness is less important than chemical composition of Arbutus leaves in food selection by Poecilimon species. New Phytologist 154, 399-407.
Loranger, G., Ponge, J.F., Imbert, D., Lavelle, P., 2002. Leaf decomposition in two semi-evergreen tropical forests: influence of litter quality. Biology and Fertility of Soils 35, 247-252.

Mahalanobis, P.C., 1936. On the generalized distance in statistics. Proceedings of the National Institute of Science India 2, 49-55.

Maie, N., Behrens, A., Knicker, H., Kogel Knabner, I., 2003. Changes in the structure and protein binding ability of condensed tannins during decomposition of fresh needles and leaves. Soil Biology and Biochemistry 35, 577-589.

Mathison, G.W., Hsu, H., Soofi-Siawash, R., Recinos-Diaz, G., Okine, E.K., Helm, J., Juskiw, P., 1999. Prediction of composition and ruminal degradability characteristics of barley straw by near infrared reflectance spectroscopy. Canadian Journal of Animal Science 79, 519-523.

McTiernan, K.B., Garnett, M.H., Mauquoy, D., Ineson, P., Coûteaux, M.M., 1998. Use of NIRS in palaeoecological studies of peat. The Holocene 8, 729-740.

McTiernan, K.B., Coûteaux, M.M., Berg, B., Berg, M.P., Calvo de Anta, R., Gallardo, A., Kratz, W., Piussi, P., Remacle, J., Virzo De Santo, A., 2003. Changes in chemical composition of Pinus sylvestris needle litter during decomposition along a European coniferous forest climatic transect. Soil Biology and Biochemistry 35, 801-812.

Norris, K.H., Barnes, R.F., Moore, J.E., Shenk, J.S., 1976. Predicting forage quality by infrared reflectance spectroscopy. Journal of Animal Science 43, 889-897.

Northup, R.R., Dahlgren, R.A., McColl, J.G., 1998. Polyphenols as regulators of plant-litter-soil interactions in northern California's pygmy forest: A positive feedback? Biogeochemistry 42, 189-220.

Schlulz, H., Engelhardt, U.H., Wegent, A., Drews, H.H., Lapczynski, S., 1999. Application of near-infrared reflectance spectroscopy to the simultaneous prediction of alkaloids and phenolic substances in green tea leaves. Journal of Agricultural and Food Chemistry 47, 5064-5067.

Van Soest, P.J., Robertson, J.B., 1985. Analysis of forage and fibrous foods: A laboratory manual for animal science. Cornell University Publications, Ithaca, NY. 613 pp..

Williams, P.C., 1975. Applications of near-infrared spectrometry to analysis of cereal grains and oilseeds. Cereal Chemistry 52, 561-576.

Windham, W.R., Fales, S.L., Hoveland, C.S., 1988. Analysis for tannin concentration in Sericea lespedeza by near infrared reflectance spectroscopy. Crop Science 28, 705-708.

Yu, Z., Dahlgren, R.A., 2000. Evaluation of methods for measuring polyphenols in conifer foliage. Journal of Chemical Ecology 26, 21192140. 